\title{
Partial Characterization of a Bacteriocin (Thermocin) from Bacillus stearothermophilus RS93
}

\author{
By R. J. SHARP, A. H. A. BINGHAM, M. J. COMER \\ AND A. ATKINSON \\ Microbiological Research Establishment, Porton, Salisbury SP4 0JG
}

(Received 4 September 1978; revised 23 December 1978)

\section{INTRODUCTION}

The inhibition of bacteria by closely related species has long been observed (Gratia, 1925), and bacteriocins have been reported from a wide range of genera (see, for example, Hardy, 1975; Holland, 1975). Evidence for bacteriocins produced by the thermophile Bacillus stearothermophilus has previously been presented (Shafia, 1966; Yule \& Barridge, 1976).

This paper describes the production and some properties of a bacteriocin produced by B. stearothermophilus RS93. The bacteriocin, termed thermocin 93, inhibited the growth of all thermophilic bacilli examined but had no effect on mesophilic bacilli.

\section{METHODS}

Organisms. Bacillus stearothermophilus strain RS93 was isolated from the plant hot water supply (65士 $5{ }^{\circ} \mathrm{C}$ ) at the Microbiological Research Establishment, Porton. The strain was catalase- and oxidase-positive; nitrate and nitrite were not reduced; and starch, casein and gelatin were not digested. The strain was tolerant to $\mathrm{NaCl}(5 \%, \mathrm{w} / \mathrm{v})$ and fermented glycerol, mannitol, glucose, mannose, fructose, sorbitol and trehalose with the production of acid. The optimum growth temperature was between 60 and $65^{\circ} \mathrm{C}$; growth did not occur at 37 or $70^{\circ} \mathrm{C}$.

Bacillus caldolyticus Heinen \& Heinen 1972, obtained from Dr W. Heinen, University of Nijmegen, The Netherlands, was used to assay the bacteriocin. Other strains of thermophilic bacilli tested were obtained from the following sources: $B$. caldovelox and $B$. caldotenax from Dr Heinen, The Netherlands; B. stearothermophilus 4st and B. stearothermophilus 10 from Dr N. Welker, North Western University, Ill., U.S.A.; B. stearothermophilus RS44 isolated from sandy soil from Jean-De Monts, France; B. stearothermophilus 240 isolated from chalky soil in the Salisbury area; B. stearothermophilus 262 isolated from an Icelandic hot-water spring.

Growth media. Liquid medium for the growth of the thermophiles was that described by Sargeant $e$ al . (1971). Mesophiles were grown in peptone broth. Plating medium was Tryptone Soya Bean Agar (TSBA) (Oxoid CM131).

Thermocin production. Thermocin 93 was produced by inoculating $400 \mathrm{ml}$ medium in a 21 Erlenmeyer flask from a fresh $18 \mathrm{~h}$ plate culture of $B$. stearothermophilus RS93. The flask was shaken at $200 \mathrm{rev}$. $\mathrm{min}^{-1}$ in a Gallenkamp Orbital Incubator at $60^{\circ} \mathrm{C}$ for $18 \mathrm{~h}$. Bacteria were removed by centrifuging $(13000 \mathrm{~g}$, $15 \mathrm{~min}, 4^{\circ} \mathrm{C}$ ) and the supernatant was assayed for thermocin activity using $B$. caldolyticus as indicator.

Thermocin assay. TSBA plates ( $4 \mathrm{~mm}$ deep) were seeded with $1 \mathrm{ml}$ of a $6 \mathrm{~h}$ broth culture of $B$. caldolyticus (prepared by inoculating an overnight plate culture into $10 \mathrm{ml}$ broth) and then dried at $37^{\circ} \mathrm{C}$ for $1 \mathrm{~h}$. Wells $(8 \mathrm{~mm}$ diam.) were cut into the plates and $0.1 \mathrm{ml}$ of $B$. stearothermophilus RS93 culture supernantant was added to each. The plates were incubated at $60^{\circ} \mathrm{C}$ for $18 \mathrm{~h}$ and then the zone of inhibition around each well was measured.

Activity range. The activity range of thermocin 93 was determined using $6 \mathrm{~h}$ cultures of each test organism. TSBA plates were seeded with the appropriate organism, dried for $1 \mathrm{~h}$ and $8 \mathrm{~mm}$ diam. wells were cut into the plates. To each well was added $0 \cdot 1 \mathrm{ml}$ of $B$. stearothermophilus RS93 culture supernatant. Plates were incubated at the optimum growth temperature of the organism being tested for sensitivity to thermocin 93 .

Molecular weight determination by gel filtration. Tenfold concentrated thermocin $93(2 \mathrm{ml})$, obtained by rotary film evaporation at $70^{\circ} \mathrm{C}$ for $2 \mathrm{~h}$, was centrifuged at $10000 \mathrm{~g}$ for $15 \mathrm{~min}$. An equal volume of $0.05 \mathrm{M}$ - 
Table 1. Activity of thermocin 93 on thermophiles and mesophiles

Cultures were grown for $6 \mathrm{~h}$ and $1 \mathrm{ml}$ was used to seed a TSBA plate. Wells $(8 \mathrm{~mm}$ diam.) were cut into the plates and $0.1 \mathrm{ml}$ of $B$. stearothermophilus RS93 culture supernatant was added. Zones of growth inhibition were recorded.

$\quad$ Organism
Bacillus stearothermophilus RS93
B. stearothermophilus NCA1503
B. stearothermophilus ATCC 12016
B. stearothermophilus 240
B. stearothermophilus 262
B. stearothermophilus 10
B. stearothermophilus 4 st
B. stearothermophilus RS44
B. caldolyticus
B. caldovelox
B. caldotenax
B. amyloliquefaciens RUB500
B. subtilis 168
B. subtilis ATCC 10783
B. cereus 569 H/9
B. megaterium KM
B. globigii NCIB 8056
B. coagulans ATCC 8038
B. coagulans ATCC 12245
Escherichia coli K12 W3110
Proteus vulgaris ATCC 13315
Pseudomonas aeruginosa NCTC 6750
Staphylococcus aureus NCTC 8530
Salmonella typhimurium ATCC 23564
Rhodotorula glutinis ATCC 4054

$\begin{array}{cc}\begin{array}{c}\text { Incubation } \\ \text { temp. } \\ \left({ }^{\circ} \mathrm{C}\right)\end{array} & \begin{array}{c}\text { Inhibitory } \\ \text { zone diam } \\ (\mathrm{mm})\end{array} \\ 60 & 0 \\ 60 & 22 \\ 60 & 20 \\ 60 & 18 \\ 60 & 21 \\ 60 & 24 \\ 60 & 23 \\ 60 & 16 \\ 60 & 22 \\ 60 & 22 \\ 60 & 22 \\ 37 & 0 \\ 37 & 0 \\ 37 & 10 \\ 37 & 0 \\ 37 & 0 \\ 37 & 0 \\ 37 & 0 \\ 37 & 0 \\ 37 & 0 \\ 37 & 0 \\ 37 & 0 \\ 37 & 0 \\ 37 & 0 \\ 30 & 0 \\ & \end{array}$

$\mathrm{K}_{2} \mathrm{HPO}_{4}$ was added to $0.75 \mathrm{ml}$ of the supernatant and then loaded on to a Sephadex G-75 column (85× $1.5 \mathrm{~cm}$ ) pre-equilibrated with $25 \mathrm{~mm}$-potassium phosphate, $\mathrm{pH} 6.8$, containing $50 \mathrm{~mm}-\mathrm{KCl}$. The column was precalibrated with chymotrypsinogen (24500), myoglobin (17000), lysozyme (14400) and cytochrome $c$ (12500). Fractions $(1 \mathrm{ml})$ were collected at a fiow rate of $8 \mathrm{ml} \mathrm{h}^{-1}$ and assayed for activity as above using Nunc bioassay plates (no. 1015; Nunc U.K., Stafford, ST16 2JU).

\section{RESULTS AND DISCUSSION}

The impure extracellular preparation of thermocin 93 from shake flask cultures gave a $22 \mathrm{~mm}$ diam. zone of growth inhibition of $B$. caldolyticus. It inhibited the growth of a wide range of thermophilic bacilli, but no inhibition of mesophilic bacilli or other mesophiles was observed (Table 1). The thermocin had no inhibitory effect on the producer strain, B. stearothermophilus RS93.

Gel filtration of thermocin 93 on a precalibrated Sephadex G-75 column indicated a mol. wt of 13500. Thermocin 93 therefore appears to be smaller than the thermocin isolated from B. stearothermophilus NU10 which was estimated to have a mol. wt of 20000 (Yule \& Barridge, 1976). No evidence was found for the presence of plasmid DNA in the producing organism using $\left[{ }^{3} \mathrm{H}\right]$ thymidine and $\mathrm{CsCl}$-ethidium bromide density gradient centrifugation analysis (Le Hégarat \& Anagnostopoulos, 1977). However, recently improved methods for the detection of covalently closed circular DNA molecules from bacilli (A. H. A. Bingham, C. J. Bruton \& A. Atkinson, unpublished), using agarose-gel electrophoresis of cleared lysates, have shown that strain RS93 does contain a plasmid, although only small amounts of plasmid DNA could be detected in the cleared lysates. The amount of covalently closed circular plasmid DNA in cleared lysates was probably too low to be detected in $\mathrm{CsCl}-$ ethidium bromide density gradients. 
Physical and genetic characterization of the plasmid (pT93) is in progress and at the present time it is not known whether the bacteriocin function is coded for on pT93.

Ammonium sulphate precipitated thermocin 93 between 70 and $95 \%$ of saturation at $4{ }^{\circ} \mathrm{C}$. DNAase and RNAase (up to $250 \mu \mathrm{g} \mathrm{ml}^{-1}$ ) did not affect thermocin activity following $4 \mathrm{~h}$ incubation at $37{ }^{\circ} \mathrm{C}$. Pronase at $50 \mu \mathrm{g} \mathrm{ml}^{-1}$ reduced thermocin 93 activity to $13 \%$ of the original after $4 \mathrm{~h}$ incubation at $37^{\circ} \mathrm{C}$ and $\mathrm{pH} 7 \cdot 8$, and at $250 \mu \mathrm{g} \mathrm{ml}^{-1}$ it reduced activity to $1 \%$ under the same conditions. Similar effects were noted with chymotrypsin and trypsin.

It appears, therefore, that thermocin 93 is a small protein, but the possibility of the molecule being a glyco- or lipo-protein cannot be excluded. Thermocin 93 displays remarkable thermostability: rotary evaporation at $70^{\circ} \mathrm{C}$ for $2 \mathrm{~h}$ showed no loss in activity, whereas the half-life of the activity at $75^{\circ} \mathrm{C}$ was about $80 \mathrm{~min}$.

Optimum activity of thermocin 93 occurred at $\mathrm{pH} 7 \cdot 0$; adjustment of the $\mathrm{pH}$ to $4 \cdot 1$ or 9.4 resulted in an apparent $70 \%$ loss of activity. This effect was reversible since when the material was returned to $\mathrm{pH} 7 \cdot 0$ full activity was recovered.

The mode of action of this small, heat-stable protein is not yet understood. Experiments designed to demonstrate lysis of thermophilic bacilli by thermocin 93 have yielded variable results. It is possible that this molecule functions by affecting bacterial wall/membrane structure or function without directly promoting lysis.

\section{REFERENCES}

Gratia, A. (1925). Sur un remarquable example d'antagonisme entre deux souches de colibacille. Comptes rendus des séances de la Société de biologie 93, 1040-1041.

HARDY, K. E. (1975). Colicinogeny and related phenomena. Bacteriological Reviews 39, 464-515.

Heinen, U. J. \& Heinen, W. (1972). Characteristics and properties of a caldo-active bacterium producing extracellular enzymes and two related strains. Archiv für Mikrobiologie 82, 1-23.

Holland, I. B. (1975). Physiology of colicin action. Advances in Microbial Physiology 12, 55-139.

Le Hégarat, J. C. \& Anagnostopoulos, C. (1977). Detection and characterisation of naturally occurring plasmids in Bacillus subtilis. Molecular and General Genetics 157, 167-174.

Sargeant, K., EAST, D. N., Whitaker, A. R. \& Elsworth, R. (1971). Production of Bacillus stearothermophilus NCA 1503 for glyceraldehyde3-phosphate dehydrogenase. Journal of General Microbiology 65, iii.

SHAFIA, F. (1966). Thermocins of Bacillus stearothermophilus. Journal of Bacteriology 92, 524-525. YUle, R. \& BARRIDGE, B. D. (1976). Isolation and characterisation of a bacteriocin produced by Bacillus stearothermophilus strain NU-10. Canadian Journal of Microbiology 22, 1743-1750. 